\title{
3-D Print Celulose Nanoskin: Future Diabetic Wound Healing
}

\author{
Mohamed M. Kanjou1, Hassan Abdulhakim², Gabriel Molina de Olyveira ${ }^{3}$, Pierre Basmaji ${ }^{4}$ \\ ${ }^{1}$ SKGH Ajm., GEM International, Dubai, United Arab Emirates \\ ${ }^{2}$ Sheikh Khalifa Hospital, Ajman, United Arab Emirates \\ ${ }^{3}$ Biomedical Engineering Department, UFABC University, São Bernardo do Campo, Brazil \\ ${ }^{4}$ Innovatec's-Biotechnology Research and Development, São Carlos, Brazil \\ Email: gabriel.ufabc@gmail.com
}

How to cite this paper: Kanjou, M.M., Abdulhakim, H., de Olyveira, G.M. and Basmaji, P. (2019) 3-D Print Celulose Nanoskin: Future Diabetic Wound Healing. Journal of Biomaterials and Nanobiotechnology, 10, 190-195.

https://doi.org/10.4236/jbnb.2019.104011

Received: September 18, 2019

Accepted: October 13, 2019

Published: October 16, 2019

Copyright $\odot 2019$ by author(s) and Scientific Research Publishing Inc. This work is licensed under the Creative Commons Attribution International License (CC BY 4.0).

http://creativecommons.org/licenses/by/4.0/

\begin{abstract}
$3 \mathrm{D}$ printing is the future. It will change the way in which we produce new materials-maybe much less in factories and much easier in shops. However, biobased materials have been difficult to 3D print. Most 3D printers use heat to melt the plastic or metal to be printed, and biobased materials are degraded. But cellulose nanofibrils have a solution to this problem: the printing paste is wet and dries out to a solid material. In this work, it was showed recent wound healing in Vinous Ulcer with kidney and other health complications using bacterial cellulose 3D print membranes.
\end{abstract}

\section{Keywords}

Bacterial Cellulose, Natural Membrane, Diabetic Ulcer, Wound Healing, 3D Print, Tissue Regeneration

\section{Introduction}

Cellulose nanofibrils (nanocellulose) are the smallest fibres into which we can decompose cellulose. They are made from wood or from bactéria from agricultural or food production; they are able for 3D printing pastes because an appropriate mix of cellulose nanofibrils and water is very viscous, and can contain much water, up to $50 \%[1]$.

On drying out, these pastes produce very strong and biodegradable materials. The properties of the structure (moisture, strength and flexibility) can be modified through manipulation of the cross-links between the fibrils mainly using hyaluronic acid, condroitin sulfate and alginate with calcium [2] [3].

Structures can now be made flexible, strong and porous, and something similar. 
Manufacturing a flexible structure of bio-based materials is one challenge, since the final object becomes hard and becomes more rigid as it dries [3].

Nanocellulose increases the opportunities for creating new materials in wound healing therapy. But this development still requires moisture tests to develops 3D printing with cellulose nanofibrils for medical and biotechnology applications. There is research in developing a solution where a protein attached to a 3D-printed material can help to promote fibroblast around a wound. The aim is to obtain material for wound healing therapy to remain flexible instead of stiff [4].

Another development in this area is to obtain conductive materials using $3 \mathrm{D}$ printing, cellulose nanofibrils and carbon nanotubes. Using two gels, one conductive and one isolant, keeping dry process, researchers produced three-dimensional circuits for eletronic applications [5].

$3 \mathrm{D}$ printing is a additive manufacturing that can make revolution in the industry. It is an efficient method for complex structure and fewer weight materials. The precision of the technology turns it possible to produce newest materials with high technology than older production techniques [6] [7] [8].

Several articles were published by our group since 2015 using Nanoskin membranes for wound healing treatment with successful results in diabetic ulcers, car and other accidents, amputation required ulcers [4] [5] [6].

In this work, it was showed recent wound healing in Vinous Ulcer with kidney and other health complications using bacterial cellulose 3D print.

\section{Materials and Methods}

\subsection{Materials}

The bacterial cellulose raw material was provided from Innovatec's (São Carlos SP, Brazil). Chondroitin sulfate, hyaluronic acid, sodium alginate and calcium chloride were purchased from Sigma Aldrich.

\subsection{Methods}

1) Synthesis of bacterial cellulose and bacterial cellulose/chondroitin sulfate/hyaluronic acid

The acetic fermentation process was achieved by using glucose as a carbohydrate source. Results of this process were vinegar and a nanobiocellulose biomass. The modifying process was based on the addition of hyaluronic acid and chondroitin sulfate $(1 \% \mathrm{w} / \mathrm{w})$ to the culture medium before bacteria inoculation. Bacterial cellulose (BC) was produced by Gram-negative bacteria Gluconacetobacter xylinus, which could be obtained from the culture medium in the pure 3-D structure, consisting of an ultra fine network of cellulose nanofibers [9] [10] [11] [12].

2) Bionanocomposite preparation

In the present study, a novel biomaterial has been explored and different bacterial cellulose nanocomposites have been prepared; $\mathrm{BC} /$ chondroitin sulfate and 
hyaluronic acid cross linked with sodium alginate $(0.5 \% \mathrm{w} / \mathrm{w})$ and calcium chloride $(0.25 \% \mathrm{w} / \mathrm{w})$ for wound healing therapy [13] [14] [15].

\subsection{Characterization}

In vivo analysis-Evaluation-Clinical study under supervision of Dr. Mohamed M Kanjou and Hassan Abdulhakim. Evaluation model-geriatric patient of 60 years old with diabetic wound healing.

\section{Results and Discussion}

\section{In Vivo Analysis}

Patient enters in Sheikh Khalifa Hospital on 11/24/2016 under supervision of Dr. Mohamed M Kanjou and Hassan Abdulhakim, diagnosed with diabetic foot wound. Wound is infected and slough tissue is accumulated all over the wound. Classic dressing was used (silver dressing) but no progress. Patient is suffering from kidney failure doing kidney dialysis. In November 2016 started treatment with 3-D print Bacterial cellulose membranes (Figure 1).

After using the Bacterial cellulose material in alternate days by 1 month, it can be observed an excellent recovery of the edge and bottom of the wound and wound area reduction. Slough is easily removed. Red granulation healthy tissue is coming (Figure 2).

Then, after more 1 month, almost all slough tissue is removed by treating with 3-D print Bacterial cellulose only; granulation and building up of healthy tissue

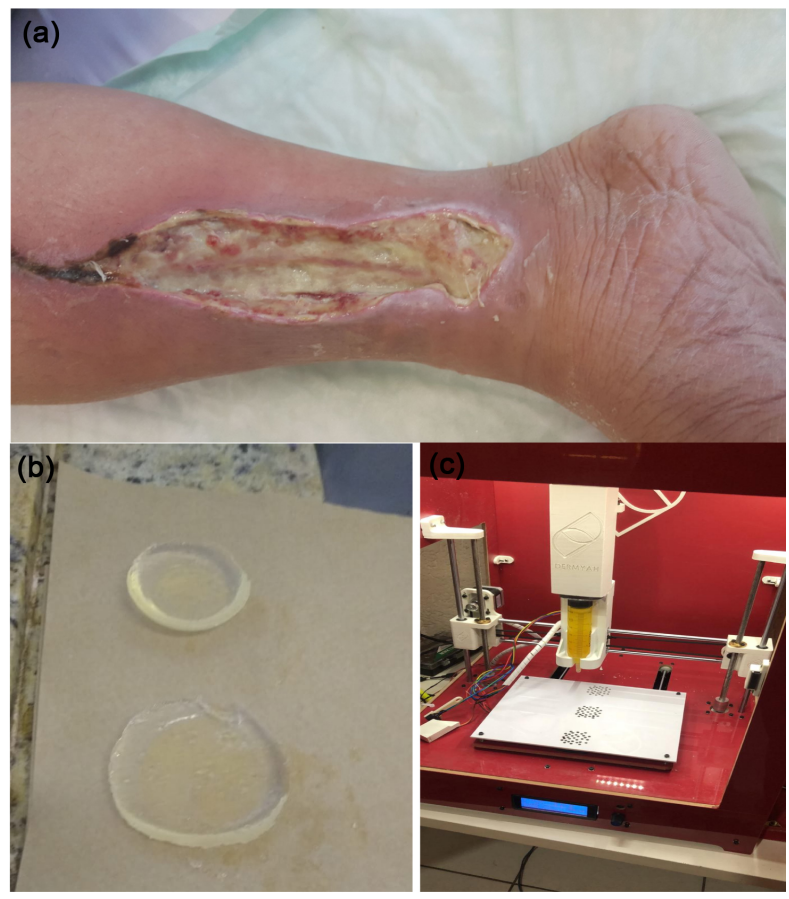

Figure 1. Wound healing treated with 3-D bacterial cellulose-biological wound dressing (a); developed membrane (b) and Nanoskin developed equipament (c). 
is coming up with approximation of skin and the wound is closing (Figure 3 ).

Finally, after 4 months of treatment, there is complete healing with minimizing the scar in wound area and able to decrease with time (Figure 4).

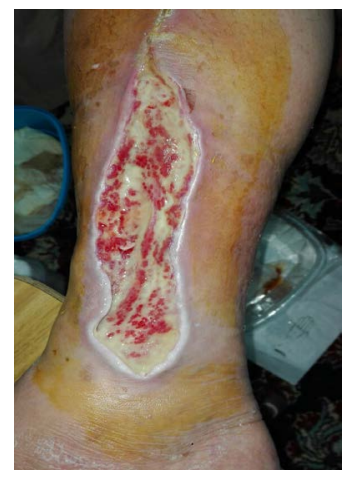

Figure 2. Wound healing evolution in 1 month and 3-D bacterial cellulose impact use with biological wound dressing.

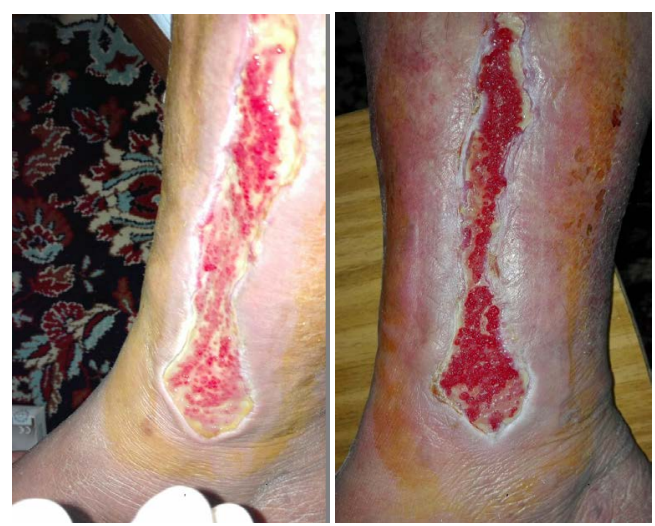

Figure 3. Wound healing evolution in 2 months and 3-D print Bacterial cellulose impact use in biological wound dressing.

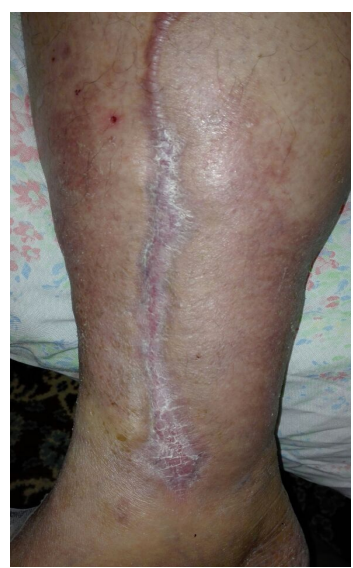

Figure 4. Complete wound healing evolution in 4 months and impact use of biological wound dressing-3-D print of bacterial cellulose. 


\section{Conclusions}

Bacterial cellulose was successfully modified by changing the fermentation medium with hyaluronic acid, chondroitin sulfate, besides of crosslinked with alginate sodium and calcium chloride, which produced suitable 3-D printed scaffolds (bacterial cellulose) for use with promissing cell viability/attachment.

Besides, it developed a new equipment for wound healing using 3-D print, which produced unique natural membranes with several applications in medicine and odontology.

In conclusion, 3-D print bacterial cellulose membranes apply to diabetic ulcers, with significant lesions and wound healing requirement; furthermore, natural membranes applications are for all population with different age.

\section{Conflicts of Interest}

The authors declare no conflicts of interest regarding the publication of this paper.

\section{References}

[1] Schaffner, M., Rühs, P.A., Coulter, F., Kilcher, S. and Studart, A.R. (2017) 3D Printing of Bacteria into Functional Complex Materials. Science Advances, 3, 1-9. https://doi.org/10.1126/sciadv.aao6804

[2] Leppiniemi, J., Lahtinen, P., Paajanen, A., Mahlberg, R., Metsä-Kortelainen, S., Pinomaa, T., Pajari, H., Vikholm-Lundin, I., Pursula, P. and Hytönen, V.P. (2017) 3D-Printable Bioactivated Nanocellulose-Alginate Hydrogels. ACS Applied Materials \& Interfaces, 9, 21959-21970. https://doi.org/10.1021/acsami.7b02756

[3] Greca, L.G., Lehtonen, J., Tardy, B.L., Guo, J. and Rojas, O.J. (2018) Biofabrication of Multifunctional Nanocellulosic 3D Structures: A Facile and Customizable Route. Materials Horizons, 5, 408-415. https://doi.org/10.1039/C7MH01139C

[4] Al Mualla, S., Al Nabooda, M., Salman, N., Basmaji, P., De Olyveira, G., Manzine Costa, L., Da Costa Oliveira, J. and Francozo, G. (2018) Special Nanoskin-ACTBiological Membranes from Deep Wounds. Journal of Biomaterials and Nanobiotechnology, 9, 79-88. https://doi.org/10.4236/jbnb.2018.91007

[5] El-Hoseny, S.M., Basmaji, P., Olyveira, G.M., Costa, L.M.M., Alwahedi, A.M., Oliveira, J.D.C. and Francozo, G.B. (2015) Natural ECM-Bacterial Cellulose Wound Healing-Dubai Study. Journal of Biomaterials and Nanobiotechnology, 6, 237-246. https://doi.org/10.4236/jbnb.2015.64022

[6] Mualla, S.A., Farahat, R., Basmaji, P., Olyveira, G.M., Costa, L.M.M., Oliveira, J.D.C. and Francozo, G.B. (2016) Study of Nanoskin ECM-Bacterial Cellulose Wound Healing/United Arab Emirates. Journal of Biomaterials and Nanobiotechnology, 7, 109-117. https://doi.org/10.4236/jbnb.2016.72012

[7] Costa, L.M.M., Olyveira, G.M., Basmaji, P. and Filho, L.X. (2012) Bacterial Cellulose towards Functional Medical Materials. Journal of Biomaterials and Tissue Engineering, 2, 185-196. https://doi.org/10.1166/jbt.2012.1044

[8] Olyveira, G.M., Costa, L.M.M. and Basmaji, P. (2013) Physically Modified Bacterial Cellulose as Alternative Routes for Transdermal Drug Delivery. Journal of Biomaterials and Tissue Engineering, 3, 227-232.

https://doi.org/10.1166/jbt.2013.1079 
[9] Filho, L.X., OLyveira, G.M., Costa, L.M.M. and Basmaji, P. (2013) Novel Electrospun Nanotholits/PHB Scaffolds for Bone Tissue Regeneration. Journal of Nanoscience and Nanotechnology, 13, 4715-4719. https://doi.org/10.1166/jnn.2013.7191

[10] Olyveira, G.M., Santos, M.L., Daltro, P.B., Basmaji, P., Daltro, G.C. and Guastaldi, A.C. (2014) Bacterial Cellulose/Chondroitin Sulfate for Dental Materials Scaffolds. Journal of Biomaterials and Tissue Engineering, 4, 150-154. https://doi.org/10.1166/jbt.2014.1155

[11] Olyveira, G.M., Santos, M.L., Costa, L.M.M., Daltro, P.B., Basmaji, P., Daltro, G.C. and Guastaldi, A.C. (2014). Bacterial Cellulose Nanobiocomposites for Dental Materials Scaffolds. Journal of Biomaterials and Tissue Engineering, 4, 536-542. https://doi.org/10.1166/jbt.2014.1202

[12] Olyveira, G.M., Santos, M.L., Costa, L.M.M., Daltro, P.B., Basmaji, P., Daltro, G.C. and Guastaldi, A.C. (2014) Bacterial Biocomposites for Guided Tissue Regeneration. Science of Advanced Materials, 6, 2673-2678.

https://doi.org/10.1166/sam.2014.1985

[13] Olyveira, G.M., Santos, M.L., Costa, L.M.M., Daltro, P.B., Basmaji, P., Daltro, G.C. and Guastaldi, A.C. (2015) Physically Modified Bacterial Cellulose Biocomposites for Guided Tissue Regeneration. Science of Advanced Materials, 7, 1657-1664. https://doi.org/10.1166/sam.2015.2283

[14] Olyveira, G.M., Acasigua, G.A.X., Costa, L.M.M., Scher, C.R., Filho, L.X., Pranke, P.H.L. and Basmaji, P. (2013) Human Dental Pulp Stem Cell Behavior Using Natural Nanotolith/Bacterial Cellulose Scaffolds for Regenerative Medicine. Journal of Biomedical Nanotechnology, 9, 1370-1377. https://doi.org/10.1166/jbn.2013.1620

[15] Acasigua, G.A.X., Olyveira, G.M., Costa, L.M.M., Braghirolli, D.A., Guastaldi, A.C., Pranke, P. and Basmaji, P. (2014) Novel Natural Bacterial Cellulose Nanocomposites as Potential Biomaterial for Stem Cell Therapy. Current Stem Cell Research and Therapy, 9, 117-123. https://doi.org/10.2174/1574888X08666131124135654 